\title{
A Comparison of Precipitation Measurements with a PWS100 Laser Sensor and a Geonor T-200B Precipitation Gauge at a Nival Glacial Zone in Eastern Tianshan, Central Asia
}

\author{
Yufeng Jia ${ }^{1}$, Zhongqin $\mathrm{Li}^{1,2,3, *}$, Chunhai $\mathrm{Xu}^{2}$, Shuang Jin ${ }^{2}$ and Haijun Deng ${ }^{4}$ \\ 1 College of Geography and Environment Science, Northwest Normal University, Lanzhou 730070, China; \\ jiayufeng18@126.com \\ 2 State Key Laboratory of Cryospheric Science/Tian Shan Glaciological Station, Northwest Institute of \\ Eco-Environment and Resources, Chinese Academy of Sciences, Lanzhou 730000, China; \\ xuchunhai@lzb.ac.cn (C.X.); Jinshuang@lzb.ac.cn (S.J.) \\ 3 College of Sciences, Shihezi University, Shihezi 832003, China \\ 4 College of Geographical Sciences, Fujian Normal University, Fuzhou 350007, China; denghj@fjnu.edu.cn \\ * Correspondence: lizq@lzb.ac.cn
}

Received: 9 July 2020; Accepted: 8 October 2020; Published: 10 October 2020

\begin{abstract}
Precipitation is a key process in the hydrologic cycle. However, accurate precipitation data are scarce in high mountainous areas, mainly restricted by complex topography, solid precipitation and sparse recording stations. In order to evaluate the quality of precipitation measurement, this study conducted a comparison campaign of precipitation measurements with the PWS100 laser sensor and the Geonor T-200B rain gauge for an entire year from 30 April 2018 to 1 May 2019 at an elevation of $3835 \mathrm{~m}$ in a nival glacial zone in eastern Tianshan, Central Asia. The results show that the daily precipitation values recorded by Geonor T-200B and PWS100 are well correlated and the annual precipitation amounts recorded by the two instruments differ by $7 \%$, indicating good capabilities of both instruments in solid precipitation measurement. However, the amount of precipitation measured by Geonor T-200B was $36 \mathrm{~mm}$ lower in June to August and $120 \mathrm{~mm}$ higher in the remaining months compared with the values measured by PWS100. Our study indicated that Geonor T-200B is more efficient than PWS100 in terms of catching solid precipitation measurements. According to the PWS100 data, the experiment site was dominated by solid precipitation particles, accounting for $60 \%$ of total precipitation particles. Based on the precipitation particle and in-situ air temperature measurements, a set of temperature thresholds were established to discriminate rain, sleet and snow. The threshold temperature of rainfall and snowfall is -1.5 and $8{ }^{\circ} \mathrm{C}$, respectively. When air temperature ranges from -1.5 to $8{ }^{\circ} \mathrm{C}$, sleet occurs, meanwhile the ratio of rain to snow depends on air temperature.
\end{abstract}

Keywords: precipitation comparison; Geonor T-200B; PWS100; precipitation types; temperature threshold; mountainous areas; Tianshan; Central Asia

\section{Introduction}

Precipitation is of paramount importance for the support of life and is essential for many human activities, especially as the primary source of drinking water and in the agricultural sector [1]. Precipitation is also a key process in the hydrologic cycle and the major driving process of terrestrial hydrology [2-4]. In western China, mountainous watersheds are the source areas of runoff and water resources, and accurate precipitation measurements are extremely important for calculating the 
water balance and understanding the water cycle processes in these high mountains [5]. However, accurate precipitation data are scarce in mountainous areas, mainly restricted by complex topography, solid precipitation and sparse recording stations [6,7]. In the past few decades, research on solid precipitation in mountainous areas has become a topic of concern. All knowledge of precipitation measurement errors has relied on field experiments. Back in 1955, the World Meteorological Organization (WMO) conducted the first precipitation measurement intercomparison; since then, many studies have been carried out [5,8-14]. The main objectives of the Solid Precipitation Intercomparison Experiment (SPICE) organized by the WMO Commission for Instruments and Methods of Observation were to define and validate the field references for gauge intercomparison and to assess the automatic systems used in the operational networks for solid precipitation observations [15].

Studies comparing different precipitation measurement devices highlight the challenges of accurate precipitation measurement [1,4,16-18]. Instrument comparisons are helpful for determining the capabilities and design limitations of different sensors regarding accuracy and precision of water amount estimates and precipitation intensity measurements [3]. In recent years, several studies have been conducted to compare ground precipitation measurements between diverse, collocated instruments $[1,17,18]$. Differences can even be found between instruments of the same type at the same site [19].

Solid precipitation measurements, in particular, are subject to large measurement errors, due primarily to undercatch caused by wind. Additional uncertainty may result from snowfall collecting on the gauge and drifting snow accumulating within wind shields [20]. There have been many studies on undercatch of solid precipitation over the past several decades by researchers using different gauges [21-26]. Several national monitoring agencies, including those in Canada, the United States and Europe, have been using the Geonor T-200B accumulating precipitation gauge and Alter shield to measure solid precipitation for more than a decade in their national observation networks and research programs [27]. Since the start of the trial on 12 December 2011, a new optical present weather sensor, the PWS100 (Campbell Scientific, USA), developed by Campbell Scientific, has been evaluated for precipitation measurement. It measures accumulation, particle size distribution and particle type by counting the forward scattering of four sheets of laser light in horizontal and vertical planes as individual particles of precipitation fall through [28]. Due to the different mechanisms and advantages of these two instruments, the synchronous measured data recorded by Geonor T-200B (Norway) and PWS100 may be crucial in terms of examining the actual volume of solid precipitation.

Urumqi River is a major water supply for Urumqi, the provincial capital city of the Xinjiang Uyghur Autonomous Region. The source area of this river is located at a nival glacial zone on the northern slope of the eastern Tianshan and the core area of arid and semiarid Central Asia. Climatological observations around this area were launched when the Tianshan Glaciological Station was established in 1959. During the third WMO precipitation measurement intercomparison experiment (1985-1987), the Chinese standard precipitation gauge (CSPG) and the Hellmann gauge were first compared using the double fence intercomparison reference (DFIR) shield as a reference configuration in this area. The wetting loss, evaporation loss, wind-induced undercatch and trace precipitation of the CSPGs were well quantified based on massive observation data $[8,14]$. However, for the first time in this area, by comparing observed results between Geonor T-200B and PWS100, this study is intended to discover the difference between the two instruments in precipitation measurement, to evaluate the quality of precipitation data and to reveal characteristics of different precipitation types as well. Such studies are scarce in this region and will provide a reference for precipitation measurement in glacierized areas in arid regions of Central Asia. 


\section{Experiment Site, Instrument and Data}

\subsection{Experiment Site}

As shown in Figure $1 \mathrm{a}, \mathrm{b}$, the alpine watershed, the source area of Urumqi River lies from $86^{\circ} 46^{\prime} \mathrm{E}$ to $86^{\circ} 53^{\prime} \mathrm{E}$ in longitude and from $43^{\circ} 05^{\prime} \mathrm{N}$ to $43^{\circ} 09^{\prime} \mathrm{N}$ in latitude with an altitude range of approximately 3405 to $4486 \mathrm{~m}$. It is located in eastern Tianshan at the core area of arid and semiarid Central Asia.

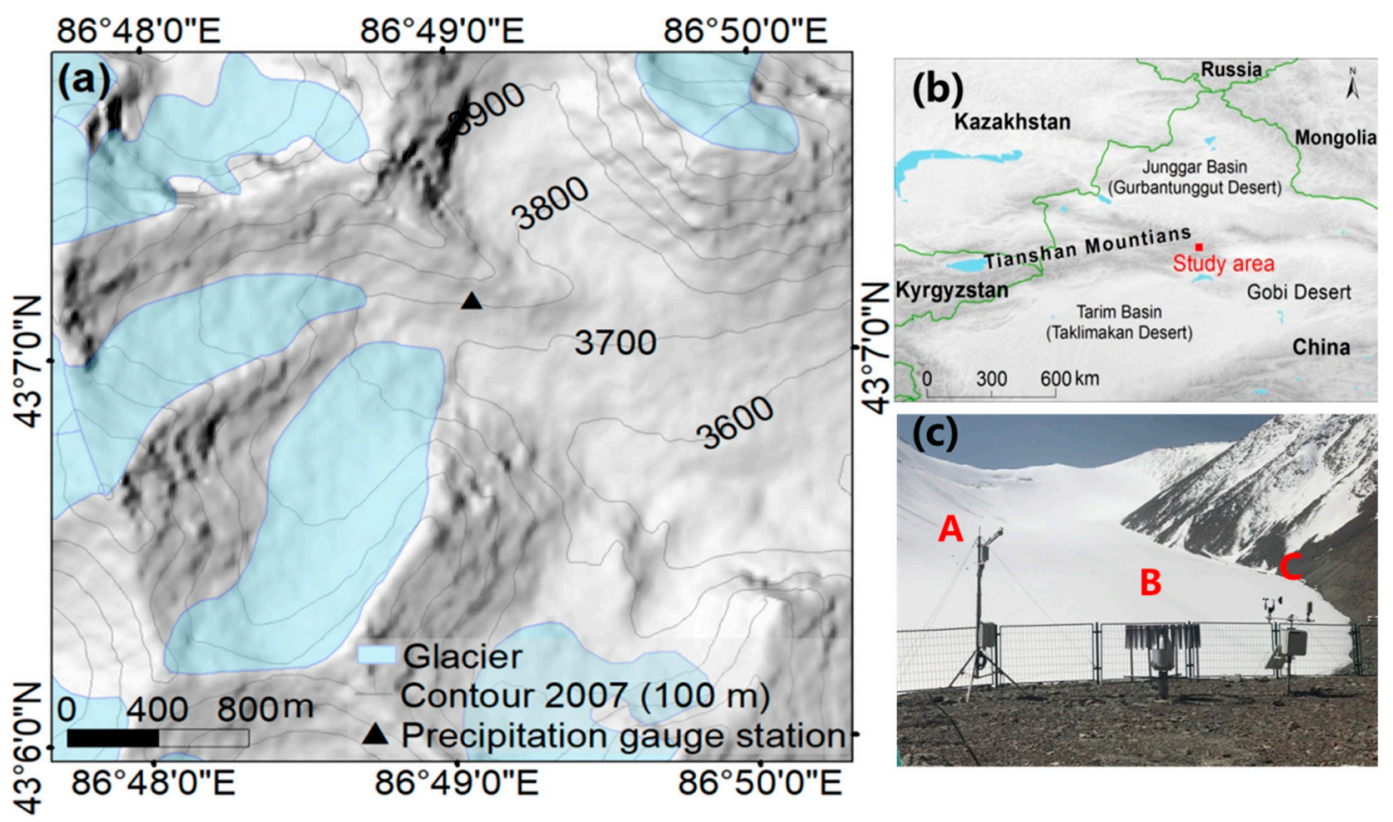

Figure 1. Experiment site description: (a) sketch map of the study catchment; (b) location of the study area; (c) experiment site with PWS100 (A), Geonor T-200B (B) and Automatic Weather Station (AWS) (C).

A westerly jet stream prevails high above the mountains, while the mountain topography converts the westerly into cyclonic and anticyclonic circulations up to $4000 \mathrm{~m}$. Near the surface, local valley winds prevail from March through to September. The annual mean air temperature is $\sim-5.1^{\circ} \mathrm{C}$ and the annual mean precipitation is $468 \mathrm{~mm}$, measured from 1959 to 2018 . Overall, $90 \%$ of the annual total precipitation occurs from May to September, predominantly as solid precipitation, such as snow, hail and sleet, at higher elevations. During winter, the temperature is controlled by the Siberian anticyclonic circulation, causing very low temperatures and little precipitation [29]. There are seven glaciers in the catchment with a total area of $5.2 \mathrm{~km}^{2}$ [30]. Glaciers are surrounded by barren rock with scarce vegetation on the valley floor. The mountain environment from 1500 to $2900 \mathrm{~m}$ above sea level is a forest zone, above $2900 \mathrm{~m}$ is an alpine meadow and above $3000 \mathrm{~m}$ is bare rock, glacial deposits and permafrost [31]. The catchment provides the principal water supply to the Urumqi River, which is used for agricultural irrigation and domestic water supplies in the city of Urumqi, the provincial capital city of the Xinjiang Uyghur Autonomous Region.

The experiment site $\left(43.12^{\circ} \mathrm{N}, 86.82^{\circ} \mathrm{E}\right)$ is situated on a flat glacial moraine ridge with an altitude of $3835 \mathrm{~m}$ in the catchment. Surrounded by mountain ridges in three directions, this site is less influenced by strong wind. During the yearly field campaign from 30 April 2018 to 1 May 2019, the mean wind speed was $2.05 \mathrm{~m} \mathrm{~s}^{-1}$. In the same period, the precipitation here was predominantly solid precipitation, and the air temperature ranged between $-24.1{ }^{\circ} \mathrm{C}$ and $9.5{ }^{\circ} \mathrm{C}$ with an average value of $-5.6{ }^{\circ} \mathrm{C}$. The present weather sensor PWS100 (Campbell Scientific) and the Geonor T-200B precipitation gauge (Norway) with a single Alter shield connected to an Automatic Weather Station (Campbell Scientific) were collocated $4 \mathrm{~m}$ apart from each other and installed in 2011 and 2017 respectively (Figure 1c). 


\subsection{Instrument and Data}

Instrument comparisons are helpful for determining the capabilities and design limitations of different sensors regarding accuracy and precision of precipitation amount. The great advantage of PWS100 over more conventional rain gauges is that it not only measures precipitation types but also gives information about size and fall velocity for all the hydrometeors passing through the sampling area [32]. In previous studies, the PWS100 was mostly reported in liquid precipitation measurement, and the Geonor T-200B has been used to measure winter precipitation [27,28,32-35]. In our field campaign, it is designed (1) to evaluate the quality of the precipitation data by comparing the two sets of measured data and (2) to reveal the characteristics of the precipitation types from PWS100 measurement which has never been described in this region.

\subsubsection{Geonor T-200b}

The Geonor T-200B (Norway) that we used is an automated weighing storage gauge with a 200- $\mathrm{cm}^{2}$ orifice and a capacity of $600 \mathrm{~mm}$ that measures the total weight of a collection bucket via a single vibrating wire transducer for the derivation of bucket weight measurements [27]. Precipitation falling through the $200-\mathrm{cm}^{2}$ orifice is collected in the bucket and weighed by converting the observed frequency of the vibrating wire transducer to the corresponding bucket weight (in $\mathrm{mm}$ ) [36]. The Geonor T-200B continuously measures the weight of accumulated snowfall in a reservoir containing antifreeze solution and oil which melt the snow and reduce evaporation. The reservoir is suspended on a wire strain gauge which vibrates at a frequency proportional to the applied strain. The reservoir and strain gauge are in a protective housing, which is surrounded by a single Alter-shield. The physical processes affecting the sensitivity of the observation are the wetting, evaporation loss and wind-induced undercatch. Additional uncertainty may result from snowfall collecting on the gauge and drifting snow and mineral dust accumulating within wind shields. The Geonor has a resolution of $0.1 \mathrm{~mm}$ SWE and an accuracy of $0.1 \%[37,38]$. It had been used by the WMO for solid precipitation measurement in the SPICE project and is widely used for both liquid and solid precipitation measurements with a variety of wind-shielding solutions $[13,27,39]$.

\subsubsection{Pws100}

The PWS100 present weather sensor is a laser-based sensor capable of determining precipitation and visibility parameters. The system can output visibility- and precipitation-related weather codes. It comprises a Digital Signal Processor (DSP) housing unit connected to a sensor arm, comprising one laser head and two sensor heads. Each of the sensor heads is 20 off-axis to the laser unit axis, one in the horizontal plane and the other in the vertical plane. The DSP housing unit is fixed via a mounting bracket to a mast, though a tripod can be used for temporary sites. A CS215 temperature and humidity sensor plugs directly into the PWS100, which is used to improve the accuracy of weather coding by the PWS100, in particular in the respect of distinguishing between different classes of hydrometeors, and it estimates precipitation intensity by accurately determining the size and velocity of individual particles. It has a structured detection volume consisting of four sheets of light, each $0.4 \mathrm{~mm}$ in depth with $0.4-\mathrm{mm}$ spacing. The area of detection is approximately $40 \mathrm{~cm}^{2}$ as defined by the overlap of the two detectors. The nominal detection size and velocity for individual particles range from 0.1 to $30 \mathrm{~mm}$ and from 0.16 to $30 \mathrm{~m} \mathrm{~s}^{-1}$, respectively, and the outputs are arranged in 34 by 34 size and velocity bins. Rainfall total resolution is $0.0001 \mathrm{~mm}$, and the accuracy is typically $\pm 10 \%$, while accuracy will be degraded in windy conditions and for frozen precipitation and very high rainfall rates. Given its design characteristics, the instrument is also capable of classifying precipitation as rain, snow, hail, etc., and to provide visibility measurements. Previous studies indicated that PWS100 consistently shows fewer counts from drops below approximately $0.8 \mathrm{~mm}$ in diameter and shows better sensitivity to larger rain droplets $[4,34,40]$. 


\subsubsection{Data}

In addition to the precipitation data simultaneously recorded by the PWS100 laser present weather sensor and the Geonor T-200B precipitation gauge, the common atmospheric parameters were also observed by diverse sensors on the Automatic Weather Station (Campbell Scientific), which include the air temperature and relative humidity, which were measured using a HC2-S3 sensor, and the wind speed was measured using a Young 05103 ultrasonic wind sensor, with a resolution of $0.01 \mathrm{~m} \mathrm{~s}^{-1}$ and an accuracy of $2 \%$. The meteorological data gathered from the instruments recorded with a one-minute time resolution can be converted to daily average. In this study, daily precipitation data derived from the PWS100 and the Geonor T-200B measurements (without correction) and air temperature, relative humidity and wind speed data from 1 May 2018 to 30 April 2019 are analyzed.

\section{Results and Discussion}

\subsection{Comparison of Measured Precipitation from Two Instruments}

\subsubsection{Daily Precipitation Amount and Days}

During the experiment period of 1 May 2018 to 30 April 2019, the total precipitation amount recorded by Geonor T-200B and PWS100 was $674 \mathrm{~mm}$ and $627 \mathrm{~mm}$, respectively. Daily precipitation derived from these two instruments were also strongly correlated $\left(\mathrm{R}^{2}=0.87, n=365, p<0.01\right)$ and the annual precipitation amount recorded by the two instruments differs by $7 \%$; the difference is little compared with comparative data for other instruments [4,41] (Figure 2a). The root mean squared error (RMSE) was rather small (1.43 mm).
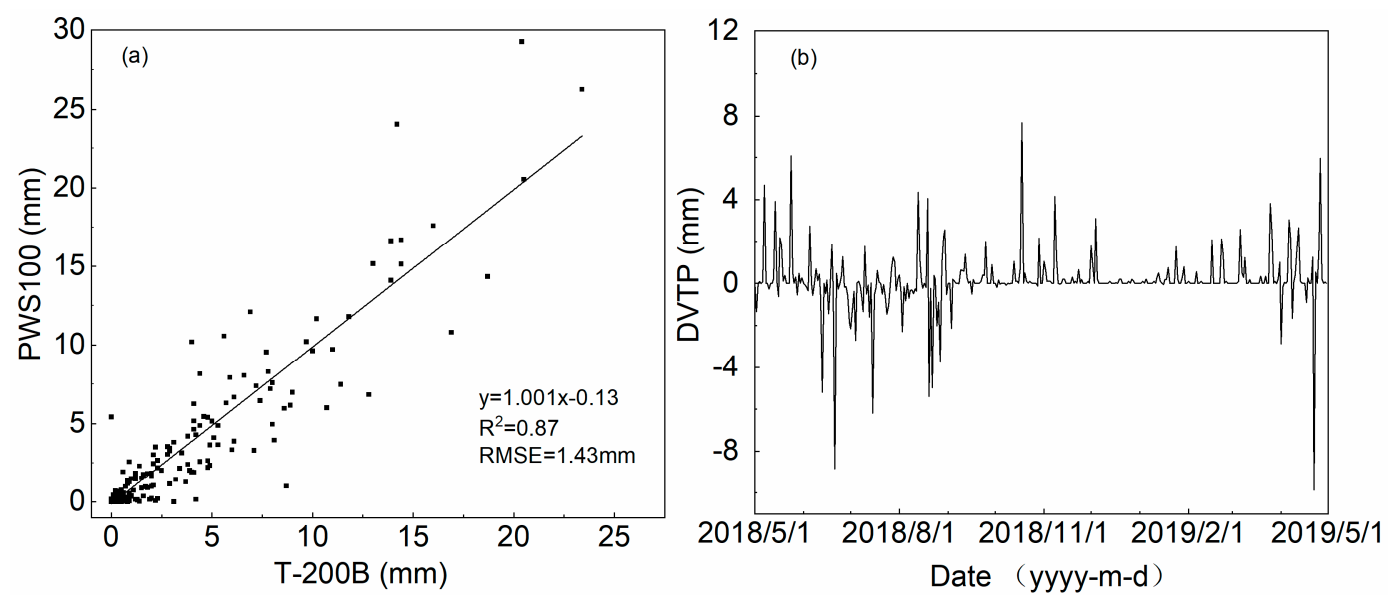

Figure 2. Correlation between daily precipitation amounts collected by Geonor T-200B and PWS100 (a); the variation of difference value of precipitation amount recorded by Geonor T-200B and PWS100 (DVTP) from 1 May 2018 to 30 April 2019 (b).

However, a small seasonal difference was found between these two observed data sets. Figure $2 \mathrm{~b}$ shows that the difference in values between the Geonor T-200B and PWS100 measurements (DVTP, Geonor T-200B recorded precipitation amount minus PWS100 recorded precipitation amount) varies with time, showing that it fluctuates largely with a value of $-36 \mathrm{~mm}$ during June to August and of $83 \mathrm{~mm}$ (positive) during the rest of the months. This indicates that PWS100 records more precipitation during summer months while Geonor T-200B records more precipitation during winter months.

The numbers of precipitation days are presented in Figure 3. It indicates that during the experiment period of 1 May 2018 and 30 April 2019, the total precipitation days recorded by Geonor T-200B and PWS100 were 213 and 190, respectively. This is consistent with the precipitation amount observed by Geonor T-200B which was a little higher than that by PW100 during the same period. There were 174 precipitation days simultaneously observed by both Geonor T-200B 
and PWS100, and 39 precipitation days were recorded by only Geonor T-200B, mainly in the winter, and 16 precipitation days recorded only by PWS100, in different seasons. As a result, Geonor T-200B recorded more precipitation days. The reason for it may be complicated and partially because the Geonor T-200B was affected by ambient inputs, such as drifting snow [20] or mineral dust, and also because the PWS100 has a lower sensitivity to snow particles below approximately $0.8 \mathrm{~mm}$ in diameter and a higher sensitivity to larger rain droplets $[1,28]$.

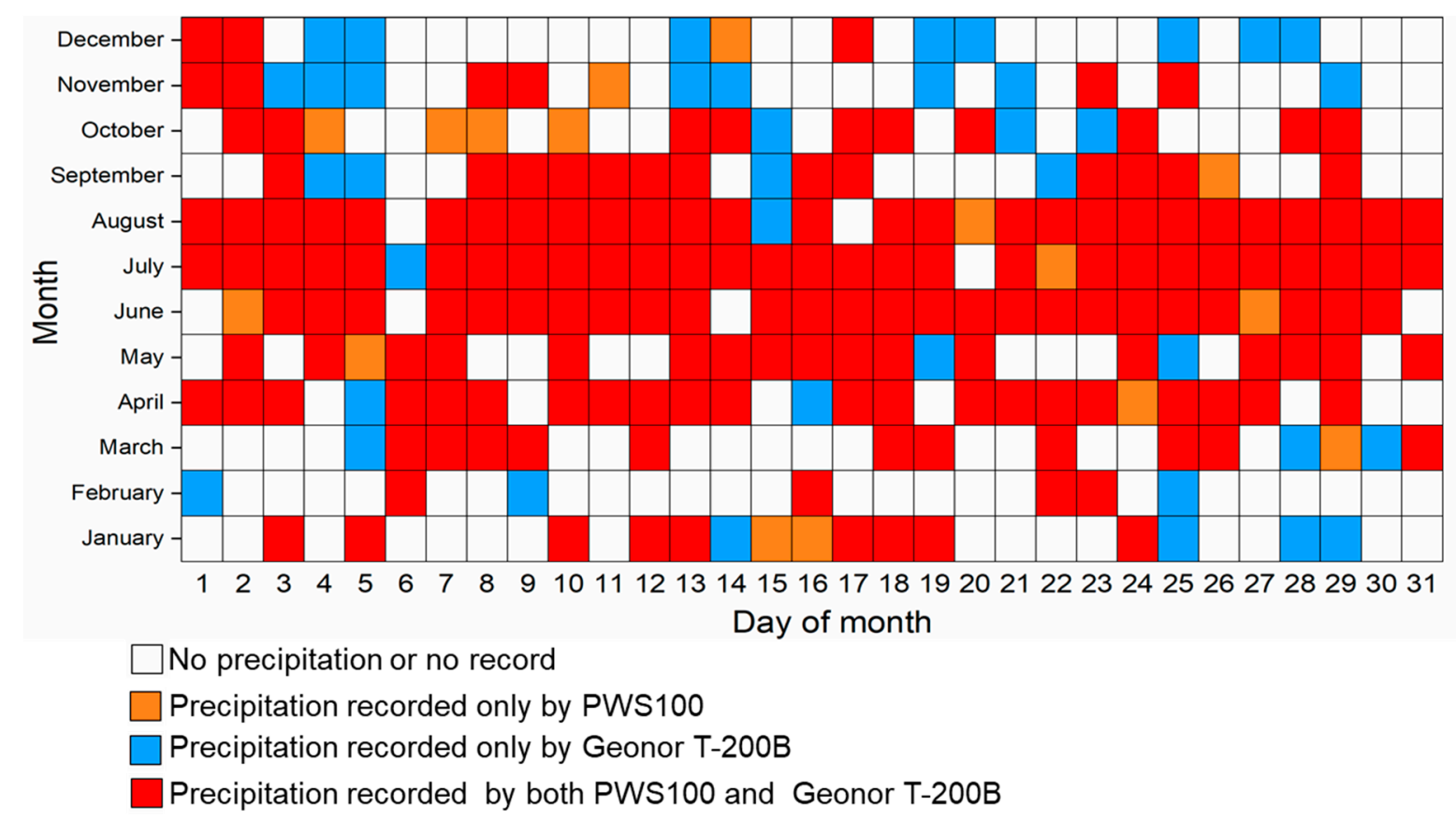

Figure 3. Precipitation days recorded by Geonor T-200B and PWS100.

\subsubsection{Monthly Precipitation Amount and Days}

As shown in Table 1, both the monthly amounts of precipitation and the number of days with precipitation as observed by Geonor T-200B and PWS100 were mainly concentrated in April to September 2018 (wet period). The total precipitation amount of the wet period was $591 \mathrm{~mm}$ as observed by Geonor T-200B, accounting for $88 \%$ of its annual precipitation amount, and was $599 \mathrm{~mm}$ as observed by the PWS100, accounting for $96 \%$ of its annual value. With regards to the precipitation days, Geonor T-200B recorded 141 days during the wet period and 72 days during the dry period (from October 2018 to March 2019); meanwhile, PWS100 recorded 138 days during the wet period and 66 days during dry period. The heaviest monthly precipitations recorded by Geonor T-200B and PWS100 are both in July with $154 \mathrm{~mm}$ and $171 \mathrm{~mm}$, respectively, each covering 29 precipitation days. Compared to the data from the Geonor T-200B, the PWS100 catches less precipitation during winter months both in amount and days, particularly during December 2018 and February 2019. 
Table 1. Comparing the monthly precipitation amount and days measured on the observation site.

\begin{tabular}{ccccccc}
\hline \multirow{2}{*}{ Date } & \multicolumn{2}{c}{ T-200B } & \multicolumn{2}{c}{ PWS100 } & Ta & WS \\
\cline { 2 - 7 } & $\begin{array}{c}\text { Precipitation } \\
\text { (mm) }\end{array}$ & $\begin{array}{r}\text { Precipitation } \\
\text { Day }\end{array}$ & $\begin{array}{c}\text { Precipitation } \\
\text { (mm) }\end{array}$ & $\begin{array}{c}\text { Precipitation } \\
\text { Day }\end{array}$ & ${ }^{\circ} \mathbf{C}$ & m/s \\
\hline May-2018 & 55 & 19 & 37 & 18 & -1.2 & 2.04 \\
June-2018 & 135 & 25 & 148 & 27 & 2.8 & 1.65 \\
July-2018 & 154 & 29 & 171 & 29 & 4.0 & 1.61 \\
Auguest-2018 & 116 & 28 & 122 & 28 & 5.2 & 1.9 \\
September-2018 & 28 & 17 & 23 & 14 & 0.4 & 2.12 \\
October-2018 & 26 & 13 & 13 & 14 & -5.5 & 1.98 \\
November-2018 & 15 & 14 & 6 & 7 & -12.2 & 2.39 \\
December-2018 & 7 & 11 & 0.3 & 4 & -16.5 & 2.5 \\
January-2019 & 6 & 13 & 0.3 & 11 & -16.4 & 1.98 \\
February-2019 & 7 & 7 & 0.4 & 4 & -15.3 & 2.41 \\
March-2019 & 22 & 14 & 9 & 12 & -9.7 & 2.02 \\
April-2019 & 103 & 23 & 98 & 22 & -3.4 & 1.94 \\
Annual & 674 & 213 & 627 & 190 & -5.7 & 2.05 \\
\hline
\end{tabular}

\subsection{Influencing Factors of Precipitation Measurement}

\subsubsection{Precipitation Type}

The observed daily and monthly precipitation data both demonstrate that compared to Geonor T-200B, the PWS100 captured more precipitation during summer months (from June 2018 to August 2018) and less precipitation and days during May 2018 and September 2018 to April 2019, particularly during December 2018 to February 2019. Detailed analysis of individual precipitation data indicates that the higher values of precipitation recorded by PWS100 corresponded to higher temperature and heavy precipitation. Geonor T-200B performance is more efficient in terms of catching light precipitation when temperature and precipitation are very low during winter months.

We found that the difference in precipitation measurement of these two instruments could be attributed to the precipitation type. Figure 4 gives the monthly difference value between Geonor T-200B and PWS100 measurements (DVTP, Geonor T-200B recorded monthly precipitation amount minus PWS100 recorded monthly precipitation amount) (a), and the monthly difference value between rain and snow particles (DVRS, the number of rain particles minus snow particles) observed by PWS100 (b), respectively. It shows that negative DVTP was coincident with positive DVRS from June to August, and vice versa in the rest of the months. This means when precipitation is dominated by rainfall, the value observed by PWS100 is higher than that observed by T-200B. Inversely, when precipitation is dominated by snowfall, the value observed by T-200B is higher than that observed by PWS100. The catch efficiency of an instrument is commonly less affected by wind or other meteorological parameters when the precipitation is dominated by rainfall and is easily influenced by wind speed when the precipitation is dominated by snowfall [12]. It was found that T-200B is more suitable for solid precipitation observation than PWS100 [1], which is consistent with our research results.

Based on the analysis above, the discrepancy of the seasonal observations of the two instruments results from the difference in the ratio between rain and snow. The measurement from the PWS100 is more suitable for months with large liquid precipitation, while the T-200B has an efficient performance of solid precipitation observation. Previous studies found that the PWS100 consistently shows fewer counts from drops below approximately $0.8 \mathrm{~mm}$ in diameter. This is consistent with it showing higher sensitivity to larger rain droplets in our study. Obviously, the larger droplets dominate the calculated total precipitation. T-200B does not underestimate the amount of precipitation and can well observe other forms of solid precipitation [1,29]. As a result of our study, these two instruments can well observe the precipitation at a nival glacial zone within the existing accuracy configuration. 


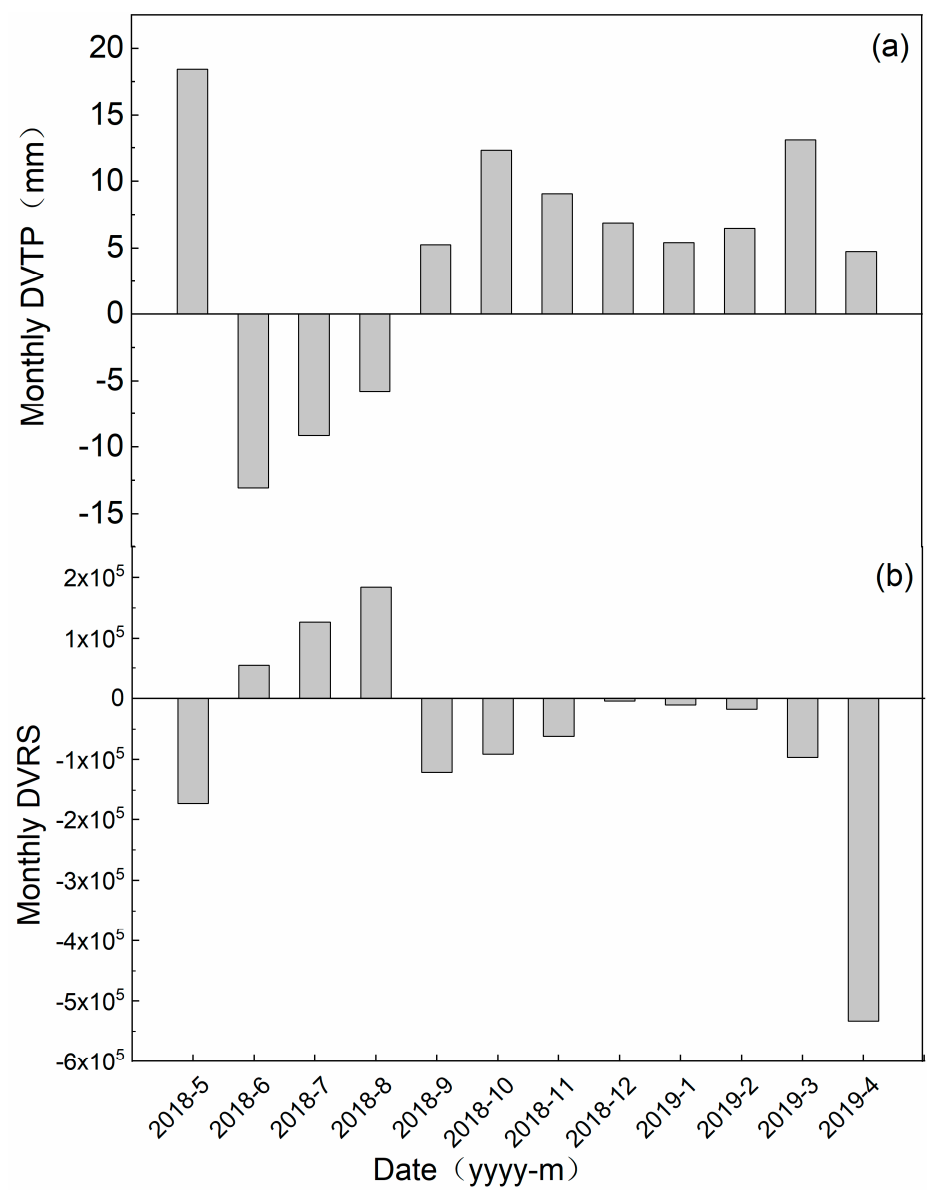

Figure 4. The variations of monthly difference value of precipitation amount recorded by Geonor T-200B and PWS100 (DVTP) (a); and monthly difference value between rain and snow particles (DVRS) from 1 May 2018 to 30 April 2019 (b).

\subsubsection{Winds}

Strong wind affects the catch efficiency of Geonor T-200B for precipitation, especially solid precipitation [28]. It also affects PWS100 by perturbing laser beams. Previous studies indicated that if the wind speed is less than $6 \mathrm{~m} \mathrm{~s}^{-1}$, its impact on Geonor T-200B catch efficiency should be small [28]. Smith et al. [42] calculated the capture rate of Geonor-DF based upon hourly data and then used it as a reference for calculating the catch efficiency of Geonor-Alt. Observed values of less than $0.2 \mathrm{~mm}$ were eliminated to void large relative errors in the calculation process. The 1-h data show that the catch efficiency of Geonor-Alt is $100 \%$ at a wind speed of $1.2 \mathrm{~m} \mathrm{~s}^{-1}$. Yang et al. [8] carried out a comparative study of solid precipitation in the source area of Urumqi River and found that the capture rate of the Chinese standard rain gauges (similar to Geonor T-200B but without an Alter shield) was as high as $86.2 \%$. The high capture rate is most likely attributed to the low wind speed in the study area and because most precipitation occurs in spring and summer when wind speed is much lower.

The observed wind speed at the experiment site from 5 May 2018 to 30 April 2019 was comparatively low, with an average of $2.05 \mathrm{~m} \mathrm{~s}^{-1}$. The highest and lowest values are $4.44 \mathrm{~m} \mathrm{~s}^{-1}$ and $0.08 \mathrm{~m} \mathrm{~s}^{-1}$, respectively. During this experiment period, a relatively large wind speed occurred in 31 days, ranging from 3 to $4.44 \mathrm{~m} \mathrm{~s}^{-1}$. In these 31 days, precipitation was observed by T-200B and PWS 100 on 13 days and 9 days, respectively, and the total precipitation amount was $27 \mathrm{~mm}$ and $22 \mathrm{~mm}$, respectively. The analysis of these individual precipitation data indicates that the precipitation recorded by the two instruments were well coincident with each other. As a result, we conclude that wind has little influence on the observations of the two instruments in this case. 


\subsection{Temperature Threshold of Different Types of Precipitation}

\subsubsection{Characteristics of Precipitation Types}

Precipitation types have great effects on surface runoff and energy balance. However, most weather stations only record a precipitation amount without discriminating its type. The precipitation types in the headwaters of the Urumqi River have never been observed and quantified in previous studies. In this study, the PWS100 is designed to subdivide the precipitation into nine types according to physical quantities and also measures the number of each precipitation type's particles, which will bring insight into the precipitation. The nine types of precipitation include drizzle, freezing drizzle, rain, freezing rain, snow grains, snowflakes, ice pellets, hail and graupel (Table 2).

Table 2. The number of precipitation particles recorded by the PWS100.

\begin{tabular}{|c|c|c|c|c|c|c|c|c|c|c|c|}
\hline Date & Drizzle & $\begin{array}{l}\text { Freezing } \\
\text { Drizzle }\end{array}$ & Rain & $\begin{array}{l}\text { Freezing } \\
\text { Rain }\end{array}$ & $\begin{array}{l}\text { Snow } \\
\text { Grains }\end{array}$ & Snowflakes & Ice Pellets & Hail & Graupel & $\begin{array}{c}\mathrm{Ta} \\
\left({ }^{\circ} \mathrm{C}\right)\end{array}$ & $\begin{array}{l}\text { RH } \\
(\%)\end{array}$ \\
\hline May-2018 & 438 & 1660 & 355 & 248 & 88,525 & 85,355 & 292 & 49 & 97 & -1.2 & 55 \\
\hline June-2018 & 51,487 & 2277 & 362,149 & 135 & 105,012 & 201,351 & 19,842 & 578 & 85 & 2.8 & 74 \\
\hline July-2018 & 56,407 & 1147 & 371,717 & 66 & 83,952 & 160,857 & 19,392 & 853 & 63 & 4 & 74 \\
\hline August-2018 & 59,594 & 3022 & 393,426 & 78 & 82,073 & 127,689 & 14,775 & 468 & 193 & 5.2 & 69 \\
\hline September-2018 & 1182 & 689 & 440 & 28 & 57,999 & 63,193 & 1231 & 88 & 69 & 0.3 & 54 \\
\hline October-2018 & 0 & 438 & 0 & 10 & 48,451 & 42,951 & 8 & 10 & 40 & -5.5 & 50 \\
\hline November-2018 & 0 & 0 & 0 & 0 & 43,040 & 18,727 & 0 & 0 & 59 & -12.2 & 47 \\
\hline December-2018 & 0 & 0 & 0 & 0 & 3293 & 1005 & 12 & 0 & 12 & -16.5 & 42 \\
\hline January-2019 & 0 & 0 & 0 & 0 & 8977 & 1527 & 0 & 0 & 12 & -16.4 & 40 \\
\hline February-2019 & 0 & 0 & 0 & 0 & 15,310 & 2143 & 0 & 0 & 25 & -15.3 & 40 \\
\hline March-2019 & 0 & 2 & 0 & 0 & 64,082 & 32,680 & 3 & 1 & 65 & -9.7 & 42 \\
\hline April-2019 & 294 & 4886 & 17 & 313 & 265,109 & 267,500 & 479 & 194 & 305 & -3.4 & 66 \\
\hline Annual & 169,402 & 14,121 & $1,128,104$ & 878 & 865,823 & $1,004,978$ & 56,034 & 2241 & 1025 & -5.7 & 54 \\
\hline
\end{tabular}

According to the results from PWS100 measurements, on the annual scale from 1 May 2018 to 30 April 2019, the precipitation particles at the observation site were mainly rain particles, accounting for $35 \%$ of the total, followed by snowflakes and snow grains particles, with the ratio of $31 \%$ and $27 \%$ in the total number of particles, respectively. However, the total number of rain-related particles (drizzle, freezing drizzle, rain and freezing rain) and solid particles (snowflakes, snow grains, ice pellets, hail and graupel) account for $40 \%$ and $60 \%$ of the total particles, respectively; therefore, the experiment site was dominated by solid precipitation.

On the monthly scale, the highest total number of particles was observed from June to August, where rain-related particles and solid particles account for $61 \%$ and $39 \%$ of the total particle numbers, respectively. For the other months, solid particles dominated, accounting for $99 \%$ of the total number of particles.

Comparing with the average monthly temperature in Table 2, it is found that rain particles basically appeared in May. Due to the low temperature of $-1.2{ }^{\circ} \mathrm{C}$, the number was far lower than snow particles. From June to August, the temperature rose to a positive figure with an average value of $4{ }^{\circ} \mathrm{C}$, and rain-related particles increased and exceeded solid particles. In October, as temperature dropped to negative again with an average value of $-5.5{ }^{\circ} \mathrm{C}$, drizzle and rain particles were no longer observed; meanwhile, the number of snow particles rose. From the monthly distribution of different particles, only snow grains, snowflakes and graupel particles can be observed throughout the year. The remaining particles only appear in some months, depending on air temperature (Ta) and possibly on relative humidity $(\mathrm{RH})$.

\subsubsection{Relationship between Precipitation Types and Temperature}

The distribution of rain and snow particles with daily mean air temperature (Ta) demonstrates that the snow particles occur when $\mathrm{Ta}<8^{\circ} \mathrm{C}$ and peak at about $2{ }^{\circ} \mathrm{C}$. When $\mathrm{Ta}>5^{\circ} \mathrm{C}$, the number of snow particles decreases rapidly. Rain particles occur when $\mathrm{Ta}>-1.5^{\circ} \mathrm{C}$ and the mass distribution is 
when $\mathrm{Ta}>0{ }^{\circ} \mathrm{C}$. As a result, the threshold temperature of rainfall and snowfall are $-1.5^{\circ} \mathrm{C}$ and $8{ }^{\circ} \mathrm{C}$, respectively (Figure 5).

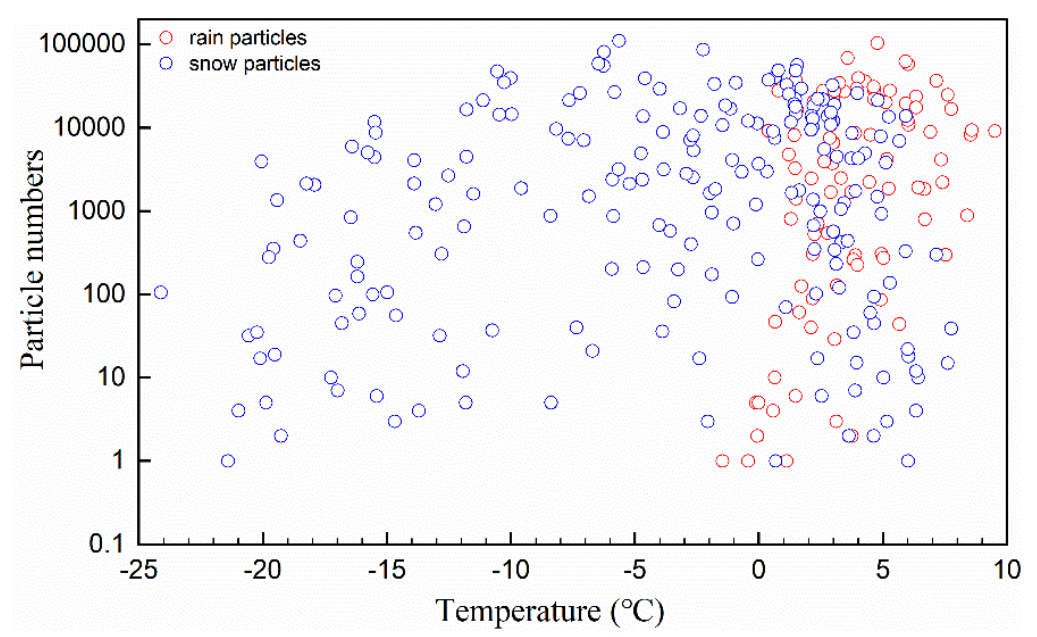

Figure 5. Distribution of rain and snow particles with temperature. (with a logarithmic scale on the Y-axis).

When the air temperature is between $-1.5^{\circ} \mathrm{C}$ and $8{ }^{\circ} \mathrm{C}$ in June to August, mixed precipitation (also referring to sleet) occurs. The difference in value between rain and snow particles (DVRS, rain particle numbers minus snow particle numbers) with Ta when mixed precipitation occurs from June to August is shown in Figure 6. It indicates that there is a positive correlation between the two series $\left(R^{2}=0.32\right.$, $\mathrm{n}=74, p<0.05$ ). In detail, in June, Ta just rises to a positive value, and rain/snow proportion was highly sensitive to air temperature. The correlation between these two series is stronger. In July-August, as Ta continues to rise and approaches the snowfall threshold, snow particles decrease dramatically and the sensitivity of rain/snow proportion to Ta becomes weaker, therefore the correlation between these two series decreases. After 20 August, the temperature dropped again and the correlation of the two series improved.

It can be seen from Table 2 that in addition to rain and snow particles, all other types of particles, including drizzle, frozen drizzle, freezing rain, ice grains, hail and graupel, also increase significantly between April and August, particularly during June-August. The reason is not just a higher Ta but also may be related to a higher RH. According to Ding et al. [43], RH mainly affects the speed of the melting process. With the increase in $\mathrm{RH}$, the droplets have a higher probability to appear as sleet in a humid environment than in a dry one.

Previous studies commonly employed surface air conditions as indicators to calculate the threshold temperature of rainfall and snowfall for hydrological models [43-49]. These results show that the temperature threshold ranges between -5 and $2.8^{\circ} \mathrm{C}$ for rainfall, and between 0 and $5.5^{\circ} \mathrm{C}$ for snowfall. There was a great difference between the threshold temperature of rainfall and snowfall in different regions. The temperature threshold for rainfall from our study is $-1.5^{\circ} \mathrm{C}$, which fits into the scope of previous studies. However, the air temperature threshold for snowfall is $8^{\circ} \mathrm{C}$, which is higher than the results from the previous studies. There are two possible reasons. The first is the high elevation of the observation site that is located on glacial moraine at an altitude of $3835 \mathrm{~m}$ above sea level. A higher temperature threshold is needed for discriminating snow and rain at a higher elevation because a higher elevation implies an environment with lower pressure and thinner air, leading to less drag force on the snow droplets. Thus, the droplets can land faster in such an environment, causing a lower amount of energy to be exchanged for melting snow droplets. Therefore, the snow droplets tend to keep their original form at a higher elevation [43]. Secondly, the threshold temperature of rainfall and snowfall determined by PWS100 in this study is based on the numbers of individual precipitation particles, which is more accurate and objective and is different from the empirical methods used 
by previous studies. Thus, the results from our study provide a validation data set for empirical rainfall-snowfall separation models.

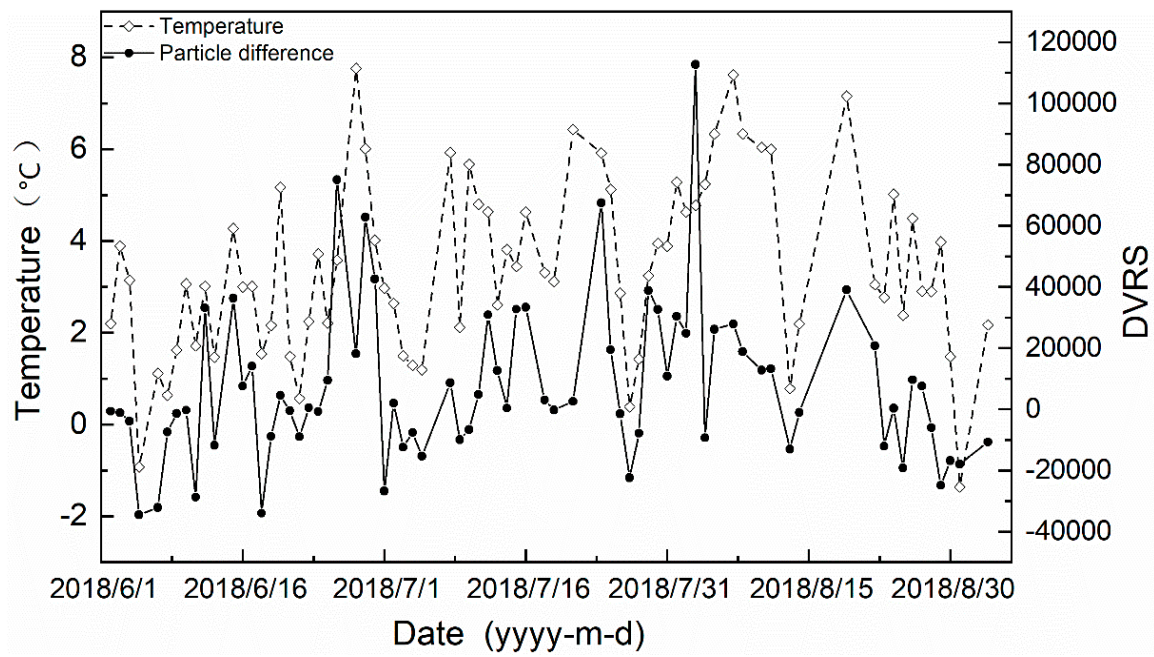

Figure 6. The difference between rain and snow particles with daily mean air temperature (Ta) from June to August in 2018.

\section{Summary and Conclusions}

This paper presents the results from a field campaign of precipitation measurement comparison launched at the headwaters of the Urumqi River in eastern Tianshan, northwestern China. By comparing the precipitation data derived from the Geonor T-200B and the PWS100 at the same location, we came to the summary and conclusions that follow:

- During the experiment period of 1 May 2018 to 30 April 2019, Geonor T-200B recorded 213 precipitation days with a total amount of $674 \mathrm{~mm}$ precipitation. At the same time, the PWS100 recorded 190 precipitation days with a total amount of $627 \mathrm{~mm}$ precipitation. In spite of the slightly lower precipitation recorded by the PWS100, there was a strong correlation $\left(R^{2}=0.87, p<0.01\right)$ between the daily data observed by the two instruments. This indicates that both instruments are suitable in terms of solid precipitation measurement in a high mountainous environment.

- There was a small seasonal difference between these two observed data sets: compared to the precipitation amount measured by the PWS100, the data from Geonor T-200B were $36 \mathrm{~mm}$ lower in June to August, when the precipitation was dominated by rainfall, and $120 \mathrm{~mm}$ higher in the remaining months, when the precipitation was dominated by solid particles. As a result, we found that that Geonor T-200B is more efficient than the PWS100 in terms of catching small solid particles in precipitation measurements, and the PWS100 may be more efficient in recording heavy precipitation in liquid forms.

- The data from the PWS100 measurements show that the experiment site was dominated by solid precipitation at the annual scale. The total number of rain-related particles (drizzle, freezing drizzle, rain and freezing rain) and solid particles (snowflakes, snow grains, ice pellets, hail and graupel) account for $40 \%$ and $60 \%$ of the total particles, respectively. On a monthly scale, June to August had the highest total number of particles, while rain-related particles and solid particles account for 61 and 39\% of total particle numbers, respectively. For the other months, solid particles dominated, accounting for $99 \%$ of the total number of particles.

- Based on the precipitation particle and in-situ air temperature measurements, a set of temperature thresholds have been established to discriminate rain, sleet and snow. The threshold temperatures of rainfall and snowfall are $-1.5^{\circ} \mathrm{C}$ and $8{ }^{\circ} \mathrm{C}$, respectively, indicating that rain particles occur when $\mathrm{Ta}>-1.5^{\circ} \mathrm{C}$ and snow particles occur when $\mathrm{Ta}<8^{\circ} \mathrm{C}$. The temperature threshold for snowfall is higher than the results from the previous studies possibly because of the high elevation of the 
experiment location and because the different method based on the measurement of individual precipitation particles. When air temperature is between $-1.5^{\circ} \mathrm{C}$ and $8{ }^{\circ} \mathrm{C}$, sleet occurs, while the ratio of rain to snow depends on air temperature.

Author Contributions: Conceptualization, Z.L. and Y.J.; methodology, Z.L.; software, Y.J.; validation, Z.L., Y.J. and H.D.; formal analysis, Y.J.; investigation, Y.J.; resources, S.J.; data curation, S.J.; writing-original draft preparation, Y.J.; writing-review and editing, Y.J., Z.L. and C.X.; funding acquisition, Z.L. All authors have read and agreed to the published version of the manuscript.

Funding: This research was funded by the Second Tibetan Plateau Scientific Expedition and Research, grant number 2019QZKK0201; the Strategic Priority Research Program of Chinese Academy of Sciences (Class A), grant numbers XDA20060201 and XDA20020102; the National Natural Science Foundation of China, grant numbers 41761134093 and 41471058; the SKLCS founding, grant number SKLCS-ZZ-2020.

Acknowledgments: We thank Xin Zhang working in the Tianshan Glaciological Station for helping draw diagrams. We also gratefully thank the reviewers for their constructive comments.

Conflicts of Interest: The authors declare no conflict of interest.

\section{References}

1. Michaelides, S.; Levizzani, V.; Anagnostou, E.; Bauer, P.; Kasparis, T.; Lane, J.E. Precipitation: Measurement, remote sensing, climatology and modeling. Atmos. Res. 2009, 94, 512-533. [CrossRef]

2. Testik, F.Y.; Barros, A.P. Toward elucidating the microstructure of warm rainfall: A survey. Rev. Geophys. 2007, 45, RG2003. [CrossRef]

3. Yan, J.; Gebremichael, M. Estimating actual rainfall from satellite rainfall products. Atmos. Res. 2009, 92, 481-488. [CrossRef]

4. Montero-Martínez, G.; Torres-Pérez, E.F.; García-García, F. A comparison of two optical precipitation sensors with different operating principles: The PWS100 and the OAP-2DP. Atmos. Res. 2016, 178, 550-558. [CrossRef]

5. Chen, R.; Liu, J.; Kang, E.; Yang, Y.; Han, C.; Liu, Z.; Song, Y.; Qing, W.; Zhu, P. Precipitation measurement intercomparison in the Qilian Mountains, north-eastern Tibetan Plateau. Cryosphere 2015, 9, 1995-2008. [CrossRef]

6. Daly, C.; Smith, J.W.; Smith, J.I.; McKane, R.B. High-resolution spatial modeling of daily weather elements for a catchment in the Oregon Cascade Mountains, United States. J. Appl. Meteorol. Climatol. 2007, 46, 1565-1586. [CrossRef]

7. Wang, L.; Chen, R.S.; Song, Y.X.; Yang, Y.; Liu, J.F.; Han, C.T.; Liu, Z.W. Precipitation-altitude relationships on different timescales and at different precipitation magnitudes in the Qilian Mountains. Theor. Appl. Climatol. 2017, 134, 875-884. [CrossRef]

8. Yang, D.; Shi, Y.; Kang, E.; Zhang, Y.; Yang, X. Results of solid precipitation measurement intercomparison in the Alpine area of Urumqi River basin. Chin. Sci. Bull. 1991, 36, 1105-1109.

9. Aizen, V.B.; Aizen, E.M.; Melack, J.M. Precipitation, melt and runoff in the northern Tien Shan. J. Hydrol. 1996, 186, 229-251. [CrossRef]

10. Adam, J.C.; Clark, E.A.; Lettenmaier, D.P. Correction of global precipitation products for orographic effects. J. Clim. 2006, 19, 15-38. [CrossRef]

11. Chen, R.S.; Song, Y.X.; Kang, E.S.; Han, C.T.; Liu, J.F.; Yang, Y.; Qing, W.W.; Liu, Z.W. A Cryosphere-Hydrology Observation System in a Small Alpine Watershed in the Qilian Mountains of China and Its Meteorological Gradient. Arct. Antarct. Alp. Res. 2014, 46, 505-523. [CrossRef]

12. Wolff, M.A.; Isaksen, K.; Petersen-Øverleir, A.; Ødemark, K.; Reitan, T.; Brækkan, R. Derivation of a new continuous adjustment function for correcting wind-induced loss of solid precipitation: Results of a Norwegian field study. Hydrol. Earth Syst. Sci. 2015, 19, 951. [CrossRef]

13. Pierre, A.; Jutras, S.; Smith, C.; Kochendorfer, J.; Fortin, V.; Anctil, F. Evaluation of catch efficiency transfer functions for unshielded and single-Alter-shielded solid precipitation measurements. J. Atmos. Ocean. Technol. 2019, 36, 865-881. [CrossRef]

14. Yang, D.Q. Research on Analysis and Correction of Systematic Errors in Precipitation Measurement in Urumqi River Basin, Tianshan. Ph.D. Thesis, Lanzhou Institute of Glaciology and Geocryology, Chinese Academy of Sciences, Lanzhou, China, 1988; p. 169. 
15. Yang, D.Q. Double Fence Intercomparison Reference (DFIR) vs. Bush Gauge for 'true' snowfall measurement. J. Hydrol. 2014, 509, 94-100. [CrossRef]

16. Tokay, A.; Kruger, A.; Krajewski, W.F. Comparison of drop size distribution measurements by impact and optical disdrometers. J. Appl. Meteorol. 2001, 40, 2083-2097. [CrossRef]

17. Lyth, D. Results from UK Met Office investigations into new technology present weather sensors. In Proceedings of the WMO Technical Conference on Instruments and Methods of Observation, IOM 96 (TD 1462), WMO, St. Petersburg, Russia, 7-9 July 2008; p. 13.

18. Lanza, L.G.; Vuerich, E. The WMO field intercomparison of rain intensity gauges. Atmos. Res. 2009, 94,534-543. [CrossRef]

19. Johannsen, L.L.; Zambon, N.; Strauss, P. Comparison of three types of laser optical disdrometers under natural rainfall conditions. Hydrolg. Sci. J. 2020, 65, 524-535. [CrossRef] [PubMed]

20. Kochendorfer, J.; Earle, M.E.; Hodyss, D.; Reverdin, A.; Roulet, Y.-A.; Nitu, R.; Rasmussen, R.; Landolt, S.; Buisan, S.; Laine, T. Undercatch Adjustments for Tipping-Bucket Gauge Measurements of Solid Precipitation. J. Hydrometeorol. 2020, 21, 1193-1205. [CrossRef]

21. Weiss, L.L. Relative catches of snow in shielded and unshielded gages at different wind speeds. Mon. Weather Rev. 1961, 89, 397-400. [CrossRef]

22. Larson, L.W.; Peck, E.L. Accuracy of precipitation measurements for hydrologic modeling. Water Resour. Res. 1974, 10, 857-863. [CrossRef]

23. Hanson, C.L. Precipitation Catch Measured by the Wyoming Shield and the Dual-Gage System. J. Am. Water Resour. Assoc. 2007, 25, 159-164. [CrossRef]

24. Goodison, B.E.; Louie, P.Y.T.; Yang, D. WMO Solid Precipitation Measurement Intercomparison; Final Report, WMO/TD 872; World Meteorological Organization: Geneva, Switzerland, 1998.

25. Yang, D.Q.; Kane, D.L.; Hinzman, L.D.; Goodison, B.E.; Metcalfe, J.R.; Louie, P.Y.T.; Leavesley, G.H.; Emerson, D.G.; Hanson, C.L. An evaluation of the Wyoming gauge system for snowfall measurement. Water Resour. Res. 2000, 36, 2665-2677. [CrossRef]

26. Sugiura, K.; Ohata, T.; Yang, D. Catch characteristics of precipitation gauges in high-latitude regions with high winds. J. Hydrometeorol. 2006, 7, 984-994. [CrossRef]

27. Smith, C. The relationship between snowfall catch efficiency and wind speed for the Geonor T-200B precipitation gauge utilizing various wind shield configurations. In Proceedings of the 77th Western Snow Conference, Canmore, AB, Canada, 20 April 2009; pp. 115-121.

28. Agnew, J. Final Report on the Operation of a Campbell Scientific PWS100 Present Weather Sensor at Chilbolton Observatory; Science \& Technology Facility Council: Swindon, UK, 2013; p. 12.

29. Li, Z.Q.; Li, C.J.; Li, Y.F.; Wang, F.T.; Li, H.L. Preliminary results from measurements of selected trace metals in the snow-firn pack on Urumqi glacier No. 1, eastern Tien Shan, China. J. Glaciol. 2007, 53, 368-373.

30. Sun, M.P.; Li, Z.Q.; Yao, X.J.; Zhang, M.J.; Jin, S. Modeling the hydrological response to climate change in a glacierized high mountain region, northwest China. J. Glaciol. 2015, 61, 127-136. [CrossRef]

31. Li, Z.Q.; Wang, W.B.; Zhang, M.J.; Wang, F.T.; Li, H.L. Observed changes in streamflow at the headwaters of the Urumqi river, eastern Tianshan, Central Asia. Hydrol. Process. 2010, 24, 217-224. [CrossRef]

32. Gires, A.; Tchiguirinskaia, I.; Schertzer, D. Multifractal comparison of the outputs of two optical disdrometers. Hydrol. Sci. J. 2016, 61, 1641-1651. [CrossRef]

33. Wauben, W.; Mathijssen, T.; Oudshoorn, C. Field evaluation of sensors for precipitation type discrimination. In Proceedings of the WMO Technical Conference on Meteorological and Environmental Instruments and Methods of Observation (CIMO TECO 2016), Madrid, Spain, 27-30 September 2016; pp. 27-30.

34. Ellis, R.A.; Sandford, A.P.; Jones, G.E. New laser technology to determine present weather parameters. Meas. Sci. Technol. 2006, 17, 1715-1722. [CrossRef]

35. Fortin, V.; Therrien, C.; Anctil, F. Correcting wind-induced bias in solid precipitation measurements in case of limited and uncertain data. Hydrol. Process. 2008, 22, 3393-3402. [CrossRef]

36. Smith, C.D.; Kamp, G.; Arnold, L.; Schmidt, R. Measuring precipitation with a geolysimeter. Hydrol. Earth Syst. Sci. 2017, 21, 5263-5272. [CrossRef]

37. He, X.B.; Ye, B.S.; Ding, Y.J. Bias correction for precipitation mesuament in Tanggula Mountain Tibetan Plateau. Adv. Water Sci. 2009, 20, 403-408. (In Chinese) 
38. Zhang, L.L.; Zhao, L.; Xie, C.W.; Liu, G.Y.; Gao, L.M.; Xiao, Y.; Shi, J.Z.; Qiao, Y.P. Intercomparison of Solid Precipitation Derived from the Weighting Rain Gauge and Optical Instruments in the Interior Qinghai-Tibetan Plateau. Adv. Meteorol. 2015, 2015, 936724. [CrossRef]

39. Wong, K.; Earle, M.; Hoover, J. The Relationship Between Manual and Geonor Automatic Gauge Measurements of Solid Precipitation in DFIR Shields During SPICE. In Proceedings of the 17th Symposium on Meteorological Observation and Instrumentation, Atlanta, GA, USA, 9-13 June 2014.

40. Campbell Scientific, Inc. PWS100 Present Weather Sensor; Instruction Manual. Revision 9/15; Campbell Scientific, Inc.: Logan, UT, USA, 2015.

41. Tokay, A.; Wolff, D.B.; Petersen, W.A. Evaluation of the new version of the laseroptical disdrometer, OTT Parsivel $^{2}$. J. Atmos. Ocean. Technol. 2014, 31, 1276-1288. [CrossRef]

42. Smith, C.D. Correcting the wind bias in snowfall measurements made with a Geonor T-200B precipitation gauge and Alter wind shield. In Proceedings of the 14th SMOI, San Antonio, TX, USA, 9-12 December 2007.

43. Ding, B.; Yang, K.; Qin, J. The dependence of precipitation types on surface elevation and meteorological conditions and its parameterization. J. Hydrol. 2014, 513, 154-163. [CrossRef]

44. Loth, B.; Graf, H.F.; Oberhuber, J.M. Snow cover model for global climate simulations. J. Geophys. Res. Atmos. 1993, 98, 10451-10464. [CrossRef]

45. Kang, E.S. Energy, water and mass balance, and discharge modeling in the Tianshan glaciated basin. Sci. China. Ser. B 1994, 24, 983-991. (In Chinese)

46. Wigmosta, M.S.; Vail, L.W.; Lettenmaier, D.P. A distributed hydrologyvegetation model for complex terrain. Water Resour. Res. 1994, 30, 1665-1679. [CrossRef]

47. Yang, Z.L.; Dickinson, R.E.; Robock, A.; Vinnikov, K.Y. Validation of the snow submodel of the biosphere-atmosphere transfer scheme with Russian snow cover and meteorological observational data. J. Clim. 1997, 10, 353-373. [CrossRef]

48. Kang, E.S.; Cheng, G.D.; Lan, Y.C.; Jin, H.J. A model for simulating the response of runoff from the mountainous watersheds of inland river basins in the arid area of northwest China to climatic changes. Sci. China Ser. D Earth Sci. 1999, 42, 52-63. [CrossRef]

49. Clark, M.P.; Slater, A.G.; Barrett, A.P.; Hay, L.E.; McCabe, G.J.; Rajagopalan, B.; Leavesley, G.H. Assimilation of snow covered area information into hydrologic and land-surface models. Adv. Water Resour. 2006, 29, 1209-1221. [CrossRef] 